\title{
Alterations in vasomotor control of coronary resistance vessels in remodelled myocardium of swine with a recent myocardial infarction
}

\author{
Dirk J. Duncker • Vincent J. de Beer • \\ Daphne Merkus
}

Received: 31 October 2007/Accepted: 23 January 2008/Published online: 5 March 2008

(C) The Author(s) 2008

\begin{abstract}
The mechanism underlying the progressive deterioration of left ventricular (LV) dysfunction after myocardial infarction (MI) towards overt heart failure remains incompletely understood, but may involve impairments in coronary blood flow regulation within remodelled myocardium leading to intermittent myocardial ischemia. Blood flow to the remodelled myocardium is hampered as the coronary vasculature does not grow commensurate with the increase in LV mass and because extravascular compression of the coronary vasculature is increased. In addition to these factors, an increase in coronary vasomotor tone, secondary to neurohumoral activation and endothelial dysfunction, could also contribute to the impaired myocardial oxygen supply. Consequently, we explored, in a series of studies, the alterations in regulation of coronary resistance vessel tone in remodelled myocardium of swine with a 2 to 3-week-old MI. These studies indicate that myocardial oxygen balance is perturbed in remodelled myocardium, thereby forcing the myocardium to increase its oxygen extraction. These perturbations do not appear to be the result of blunted $\beta$-adrenergic or endothelial NO-mediated coronary vasodilator influences, and are opposed by an increased vasodilator influence through opening of $\mathrm{K}_{\mathrm{ATP}}$ channels. Unexpectedly, we observed that despite increased circulating levels of noradrenaline, angiotensin II and endothelin- $1, \alpha$-adrenergic tone remained negligible, while the coronary vasoconstrictor influences of endogenous endothelin and angiotensin II were virtually
\end{abstract}

\footnotetext{
D. J. Duncker $(\bowtie)$ · V. J. de Beer · D. Merkus

Experimental Cardiology, Thoraxcenter,

Cardiovascular Research Institute COEUR, Erasmus MC,

University Medical Center Rotterdam, Dr Molewaterplein 50,

P.O. Box 2040, 3000 CA Rotterdam, The Netherlands

e-mail: d.duncker@erasmusmc.nl
}

abolished. We conclude that, early after MI, perturbations in myocardial oxygen balance are observed in remodelled myocardium. However, adaptive alterations in coronary resistance vessel control, consisting of increased vasodilator influences in conjunction with blunted vasoconstrictor influences, act to minimize the impairments of myocardial oxygen balance.

Keywords Myocardial infarction - Swine · Coronary blood flow $\cdot$ Myocardial oxygen balance . Exercise

\section{Introduction}

Heart failure constitutes a major cardiovascular disorder of which the incidence and prevalence are increasing, principally due to an increased survival of acute myocardial infarction (MI) in conjunction with an ageing population. The mechanism underlying the progressive deterioration of left ventricular (LV) dysfunction towards overt heart failure remains incompletely understood, but may involve (1) loss of cardiomyocytes through apoptosis [75], (2) a primary reduction in contractile function of the surviving myocardium [97], and/or (3) alterations in extracellular matrix leading to progressive LV dilation [87]. In addition, myocardial blood flow (MBF) abnormalities, resulting in impaired myocardial $\mathrm{O}_{2}$ delivery to the non-infarcted regions (leading to secondary contractile dysfunction and/ or enhanced apoptosis), have been suggested to contribute to the progression of LV dysfunction after MI [99]. For example, in vivo studies in rats [54, 55] and swine [108] indicate a reduction in MBF reserve of up to $35 \%$ in the surviving remodelled LV myocardium, 3-8 weeks after infarction. Furthermore, in patients with overt heart failure 


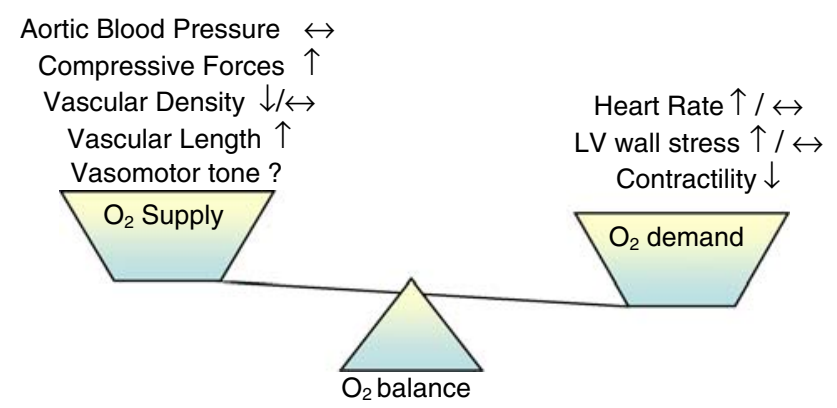

Fig. 1 Alterations in determinants of oxygen supply and demand in remodelled myocardium in swine with a 3-week-old myocardial infarction $(M I)$. The net effect of these alterations is a decrease in oxygen supply/demand ratio

[94], but also in patients with only asymptomatic LV dysfunction [95], flow reserve is reduced in the non-stenotic myocardial regions. In line with these clinical observations, we observed in a porcine model of postinfarct remodelling that during increased $\mathrm{O}_{2}$-demand induced by exercise, the increase in coronary blood flow $(\mathrm{CBF})$ is impaired resulting in perturbations in oxygen delivery $[43,70]$. The reduction in flow reserve and the perturbed oxygen delivery during exercise are caused, at least in part, by insufficient growth of the coronary vasculature to maintain flow capacity commensurate with myocardial hypertrophy, in conjunction with a decrease in diastolic pressure time index resulting from the elevated heart rate and particularly elevated LV diastolic pressures [43]. In addition, coronary vasomotor tone may also be increased secondary to neurohumoral activation and endothelial dysfunction, further adding to the perturbations in CBF. However, little is known about the alterations in vasomotor control in coronary resistance vessels within remodelled myocardium (Fig. 1). For this reason we undertook a series of studies to determine whether neurohumoral (autonomic nervous system and renin-angiotensin system), local metabolic, and endothelial control mechanisms of coronary resistance vessel tone are altered in swine with remodelled myocardium produced by a recent MI.

\section{Characteristics of $\mathrm{LV}$ remodelling and dysfunction after MI in swine}

Left ventricular remodelling was produced by permanent ligation of the left circumflex coronary artery. This ligation results in a circumscribed transmural infarction of the lateral LV wall, comprising $20-25 \%$ of the total LV [82, 96]. LV dysfunction in awake resting MI swine is characterised by $20-30 \%$ decreases in cardiac output, stroke volume and $\mathrm{LVdP} / \mathrm{d} t_{\max }$ and a tripling of $\mathrm{LV}$ filling pressure. This difference between $\mathrm{LVdP} / \mathrm{d} t_{\max }$, cardiac output and stroke volume in normal and MI swine remained constant between $\sim 10$ and $\sim 32$ days, indicating that the degree of LV dysfunction and the circulatory adaptations in MI were stable during this observation period [43]. Similarly, we observed that already during the first week after infarction significant LV remodelling occurs, consisting of LV dilation and hypertrophy that remain fairly stable between 1 and 6 weeks after infarction [98]. During exercise, cardiac output, LV systolic pressure and $\mathrm{LVdP} / \mathrm{d} t_{\max }$ increased almost in parallel in MI and normal animals up to $3 \mathrm{~km} / \mathrm{h}$, after which curves diverged (Fig. 2); $4 \mathrm{~km} / \mathrm{h}$ was also the maximally attainable exercise level for most MI swine.

Left ventricular dysfunction produced by MI results in neurohumoral activation, characterized by a trend towards elevated plasma levels of catecholamines, but normal circulating levels of renin, angiotensin II and aldosterone at rest. The latter may have been due to the increments in atrial natriuretic peptide (ANP) and endothelin, which can suppress renin and aldosterone release [83]. In resting MI swine, ANP doubled within $24 \mathrm{~h}$, recovered to $50 \%$ above normal values within 2 weeks and remained stable between 2 and 6 weeks after infarction, while renin and norepinephrine levels remained normal under resting conditions [98]. In contrast to the discrete neurohumoral activation in resting swine with $\mathrm{MI}$, exercise resulted in exaggerated increases in catecholamines and ANP and increases in endothelin, angiotensin II, and aldosterone (Fig. 3). While resting circulating levels of norepinephrine were still normal and the relative sympathetic drive in response to exercise was preserved in $\mathrm{MI}$, the cardiac responsiveness to exercise (both heart rate and $\mathrm{LVdP} /$ $\mathrm{d} t_{\max }$ ) was already blunted 3 weeks after infarction [43], likely due to $\beta$-adrenoceptor desensitization and/or downregulation [100].

\section{Myocardial $\mathrm{O}_{2}$ balance in remodelled myocardium}

Marked decreases in myocardial perfusion occur in pacinginduced severe heart failure in swine [88] and dogs [85, 90], especially in the more vulnerable subendocardial layers. Although one study in dogs indicated that the lower MBF is principally the result of a lower myocardial $\mathrm{O}_{2}$ consumption $\left(\mathrm{MVO}_{2}\right)$ [90], studies in swine suggest that the impaired perfusion is, at least in part, responsible for the deterioration of $\mathrm{LV}$ function because the interstitial edema and disruption of collagen fibers in the subendocardium resemble the ultrastuctural changes that occur with recurrent ischemia [49, 89]. In animal models of severe pressure-overload induced LV hypertrophy, selective underperfusion of the subendocardium can produce myocardial 
Fig. 2 Cardiovascular responses to exercise in normal swine and swine with a $\sim 3$ week-old MI. $0_{\mathrm{L}}=$ lying, $0_{\mathrm{S}}=$ standing. Data are mean $\pm \mathrm{SEM} ; * P<0.05$ versus $0_{\mathrm{L}}, \dagger P<0.05$ MI versus normal a corresponding exercise level. Data are from Haitsma et al. [43]
Fig. 3 Neurohumoral responses in exercising swine with a $\sim 3$ week-old MI. In the norepinephrine, epinephrine and dopamine panels, data shown for $\mathrm{N}$ represent $0_{\mathrm{L}}, 1,2,3,4$ and $5 \mathrm{~km} / \mathrm{h}$ and data for MI represent $0_{\mathrm{L}}, 1,2,3$ and $4 \mathrm{~km} / \mathrm{h}$. In all other panels, data shown for $\mathrm{N}$ represent $0_{\mathrm{L}}, 1,3$ and $5 \mathrm{~km} / \mathrm{h}$ and data for MI represent $0_{\mathrm{L}}, 1,3$ and $4 \mathrm{~km} / \mathrm{h}$. Mean data points were fitted with second order curves. $\mathrm{VO}_{2}=\mathrm{O}_{2}$-consumption. Data are mean $\pm \mathrm{SEM} ; * P<0.05$ vs $0_{\mathrm{L}},{ }^{\dagger} P<0.05 \mathrm{MI}$ versus

Normal. Data are from Haitsma et al [43]
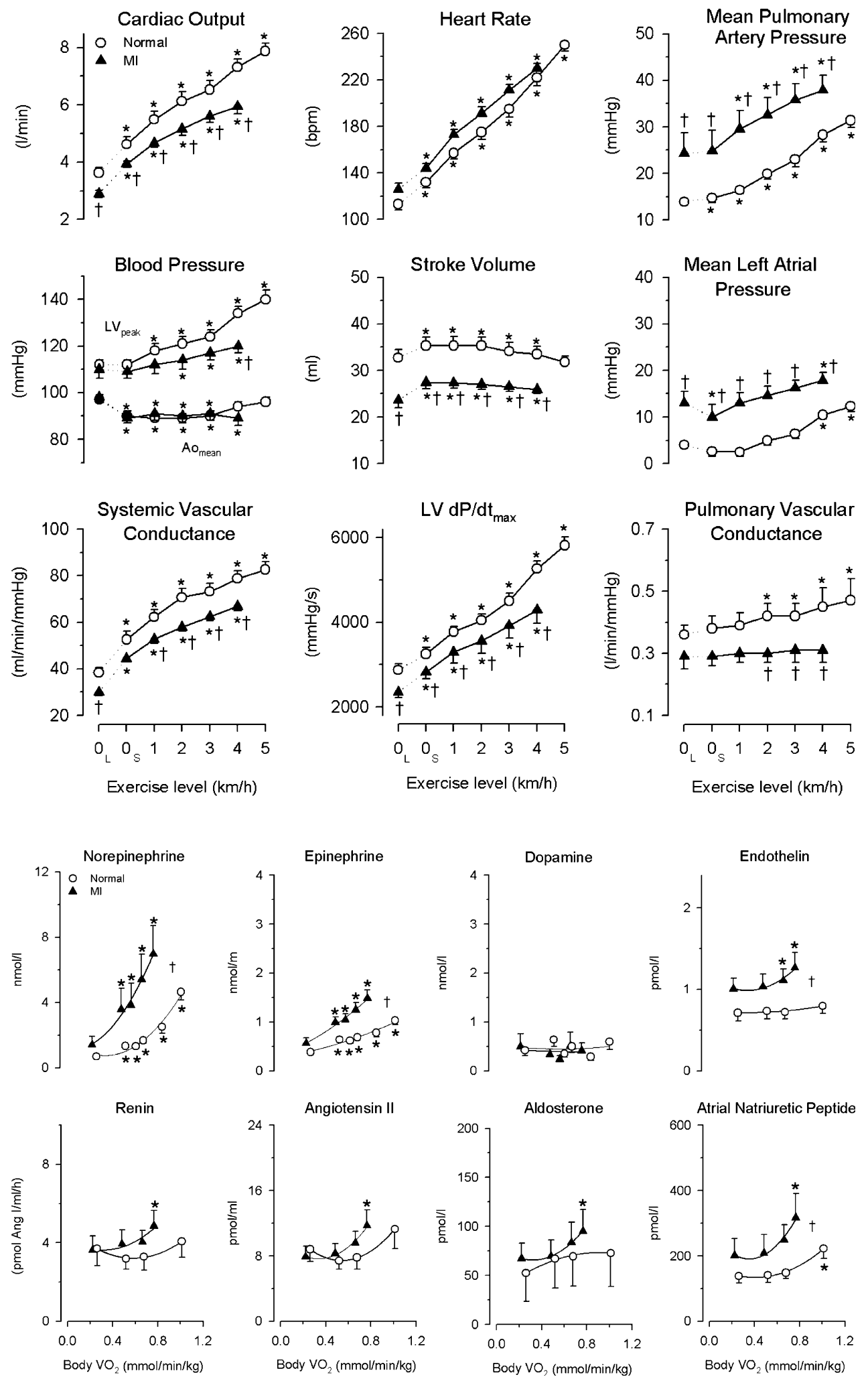

ischemia during exercise and result in post-exercise myocardial stunning [2, 102]. The contribution of perfusion abnormalities in the remote surviving myocardium to LV dysfunction after a MI remains unclear. Studies in rats demonstrated a $25-40 \%$ reduction in coronary flow reserve in the surviving myocardium at four [55] and eight [54] weeks after MI. Similarly, maximum subendocardial blood flow was blunted by $40 \%$ in anesthetized swine with heart 
failure 3 weeks after a MI [108]. We hypothesized that the decreased flow reserve could limit the increase in MBF to the hypertrophied myocardium during exercise when hemodynamic abnormalities and neurohumoral activation are exacerbated, thereby impairing myocardial $\mathrm{O}_{2}$-supply.

Three weeks after infarction, blood flow per gram of myocardium in the (remote) LV anterior wall of resting swine with MI was similar to that in normal animals (Fig. 4), confirming previous studies in rats and swine [54, 55, 108]. Interestingly, we observed a trend towards slightly higher blood flows in the outer two layers $(P=0.09)$, suggesting that despite hypertrophy of the surviving myocardium, metabolic demand in the outer, but not the inner, layers was still slightly elevated, 3 weeks after infarction [43]. During exercise, MBF increased but was redistributed in favor of the subepicardium in MI compared to normal swine. These perturbations were most likely due to increased extravascular compressive forces, resulting from a reduction in diastolic time fraction (secondary to impaired relaxation and increased heart rate) and elevated LV filling pressures [43, 97], that impede MBF, particularly in the subendocardial layers. The decreased MBF necessitated a small increase in $\mathrm{O}_{2}$ extraction that
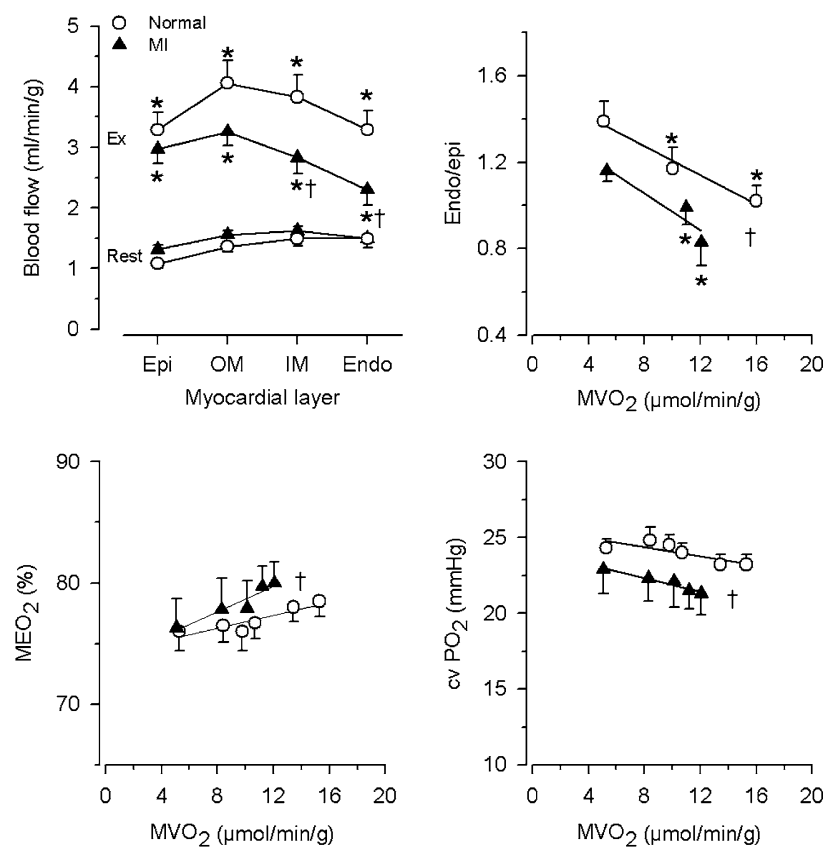

Fig. 4 Myocardial blood flow and $\mathrm{O}_{2}$-balance in the left ventricular anterior wall of $\mathrm{N}$ and MI $\sim 3$ weeks after myocardial infarction. Epi subepicardial, $O M$ outer mid; $I M$ inner mid; Endo subendocardial. $\mathrm{MVO}_{2}=$ myocardial $\mathrm{O}_{2}$-consumption $; \quad \mathrm{MEO}_{2}=$ myocardial $\mathrm{O}_{2}$ extraction; $\mathrm{CVPO}_{2}=$ coronary venous $\mathrm{O}_{2}$ tension In the top left panel data myocardial blood flow data are shown for resting (Rest, lying) conditions, and during maximum exercise $(\mathrm{Ex}, 5 \mathrm{~km} / \mathrm{h}$ in $\mathrm{N}$ and $4 \mathrm{~km} / \mathrm{h}$ in MI). Data are mean $\pm \mathrm{SEM} ; * P<0.05$ versus $0_{\mathrm{L}}{ }^{\dagger}$ $P<0.05$ MI versus Normal. Data are from Haitsma et al [43] resulted in a slightly lower coronary venous $\mathrm{O}_{2}$ tension (Fig. 4), which actually may have been underestimated as the lower myocardial capillary density in swine with MI possibly prevented a greater increase in $\mathrm{O}_{2}$ extraction [43, 70]. The observation that $\mathrm{O}_{2}$ extraction was forced to increase indicates that increases in extravascular forces are not fully compensated by a concomitant lowering of coronary vasomotor tone in remodelled myocardium during exercise. These observations prompted us to further investigate the control of coronary vasomotor tone in remodelled myocardium during exercise.

\section{Vasomotor control of the coronary microcirculation in remodelled myocardium}

\subsection{Neurohumoral control}

Cardiac dysfunction is accompanied by a hemodynamic defense reaction consisting of salt and water retention, peripheral vasoconstriction and cardiac stimulation, which serves to partially restore cardiac output and to increase systemic vascular resistance in order to maintain arterial pressure [56]. An integral part of this defense reaction involves alterations in autonomic balance, consisting of an increase in sympathetic activity and a decrease in parasympathetic activity [56].

\subsubsection{Sympathetic control}

In patients with advanced heart failure plasma noradrenaline levels are already increased under resting conditions $[11,36]$. These increased levels result principally from increased sympathetic nerve activity although impaired reuptake may also contribute [56]. Prolonged exposure to elevated noradrenaline levels results in desensitization and downregulation of the $\beta$-adrenergic receptors [8, 32, 101]. During exercise, the increases in catecholamine levels are exaggerated in patients with heart failure as compared to healthy controls [35], which is aimed at maintaining chronotropic and inotropic responses to exercise [34].

Also in swine with LV dysfunction produced by a 2-3week-old MI, we observed exaggerated increases in arterial and coronary venous catecholamine levels during treadmill exercise [23, 43], at a time when resting catecholamine levels were still in the normal range $[43,98]$. The exaggerated exercise-induced increases in catecholamine levels reflect increased sympathetic activity, which acts to maintain the chronotropic and inotropic responses to acute exercise. This concept is supported by the observation that $\beta$-adrenoceptor blockade produced slightly greater decreases in the chronotropic response during exercise in 
MI as compared to normal swine. In contrast, $\beta$-adrenoceptor blockade in MI swine resulted in a smaller decrease in global LV contractility compared to normal swine, in particular during exercise. The latter findings are consistent with a reduced left ventricular myocardial $\beta$-adrenoceptor responsiveness [100].

In normal swine and dogs, $\beta$-adrenergic receptor activation contributes to coronary vasodilatation during exercise $[27,39]$. The $\beta$-adrenergic coronary vasodilatation results in an increase in myocardial oxygen delivery that is commensurate with the increase in oxygen consumption, so that myocardial oxygen extraction and hence coronary venous $\mathrm{O}_{2}$ tension remain constant (Fig. 5). In MI swine, the net $\beta$-adrenergic vasodilator influence on the coronary circulation is maintained. However, in view of the exaggerated increases in catecholamine levels during exercise, these findings suggest a diminished $\beta$-adrenergic responsiveness of the coronary resistance vessels after MI.

In dogs, $\alpha$-adrenoceptor activation limits the exerciseinduced increase in $\mathrm{CBF}$, thereby necessitating an increase in myocardial $\mathrm{O}_{2}$ extraction, which leads to a decrease in coronary venous $\mathrm{O}_{2}$ tension $[39,51]$. In contrast, $\alpha$ adrenoceptors do not contribute to regulation of coronary blood flow in normal swine during exercise [27]. We found that, in accordance with our findings in normal swine, administration of the $\alpha$-adrenoceptor blocker phentolamine had also no effect on coronary venous $\mathrm{O}_{2}$ tension of MI swine (Fig. 5). These findings indicate that even in the presence of exaggerated increments in catecholamine levels in MI swine during exercise, $\alpha$-adrenoceptors do not contribute to regulation of tone in porcine coronary resistance vessels [23].

\subsubsection{Parasympathetic control}

The shift in the sympathovagal balance, with an increased sympathetic activity [12, 33] and a blunted parasympathetic activity is reflected in reduced heart rate variability and reduced baroreceptor reflex sensitivity $[6,12,30,76]$ in patients with advanced heart failure. We observed that a maximal dose of the muscarinic receptor blocker atropine produced a similar increase in resting heart rate in swine with MI as compared to normal swine, suggesting preserved parasympathetic activity under resting conditions [23]. In contrast, the atropine-induced increase in heart rate during exercise (particularly at higher exercise levels) was blunted in MI swine, while the increase in $\mathrm{LVdP} / \mathrm{d} t_{\max }$ was abolished [23]. These results are consistent with the concept that gradual inhibition of parasympathetic influence on the heart during exercise was more pronounced in swine with MI compared to normal swine. Importantly, these
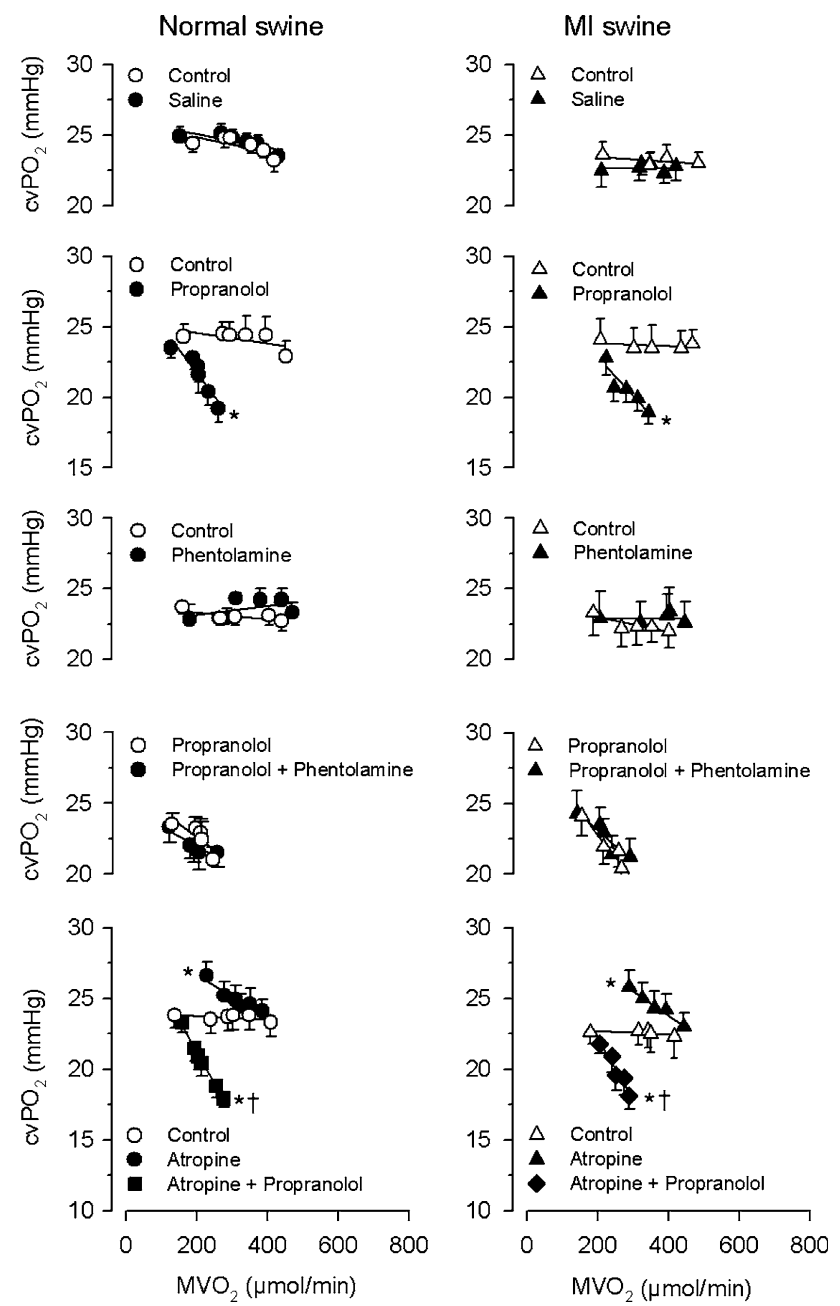

Fig. 5 Effect of saline, $\alpha$-adrenoceptor blockade (phentolamine, $1 \mathrm{mg} / \mathrm{kg}$ iv) and/or $\beta$-adrenoceptor blockade (propranolol, $0.5 \mathrm{mg} /$ $\mathrm{kg}$ iv) and of muscarinic receptor blockade (atropine, $30 \mu \mathrm{g} / \mathrm{kg} / \mathrm{min}$, iv) and/or $\beta$-adrenoceptor blockade (propranolol, $0.5 \mathrm{mg} / \mathrm{kg}$ iv) on the response of coronary venous $\mathrm{O}_{2}$ tension $\left(\mathrm{CVPO}_{2}\right)$ plotted as a function of myocardial $\mathrm{O}_{2}$ consumption $\left(\mathrm{MVO}_{2}\right)$ in seven normal and 7 MI swine. $* P<0.05$ versus corresponding Control; ${ }^{\dagger} P<0.05$ Atropine + Propranolol versus corresponding Atropine or Phentolamine + Propranolol versus corresponding Phentolamine; Data are mean \pm SEM. Data are from Duncker et al. [23]

findings suggest that after MI, at a time when parasympathetic tone under basal resting conditions is normal, a more pronounced inhibition of parasympathetic tone occurs with increasing exercise intensity. Since parasympathetic activity can presynaptically modulate sympathetic activity [1], it is likely that the greater degree of withdrawal of parasympathetic tone during exercise contributed to the exaggerated increase in sympathetic activity during exercise. This is also supported by the observation that in the presence of propranolol, the effects of atropine were no longer different between MI and normal swine [23].

In resting dogs, parasympathetic activity exerts a direct vasodilator influence on coronary resistance vessels that is 
mediated via nitric oxide [109]. In contrast, in resting swine parasympathetic activity exerts an indirect vasoconstrictor effect on the coronary resistance vessels (which wanes at increasing exercise intensity) that is mediated via inhibition of $\beta$-adrenergic vasodilatation [27]. In contrast to the loss of the inhibitory influence of the parasympathetic system on $\beta$-adrenoceptor mediated cardiostimulation, we observed that its effects on the coronary circulation were maintained in MI compared to normal swine (Fig. 5) [23]. These findings indicate that at this stage of LV dysfunction, parasympathetic control of $\beta$-adrenoceptor-mediated coronary vasodilatation is unimpaired.

\subsubsection{Angiotensin II}

The renin-angiotensin system plays an important role in cardiovascular homeostasis by contributing to the regulation of blood volume, blood pressure and vascular tone. Angiotensin II (ANG-II) exerts its effects on vascular tone through binding to the $\mathrm{AT}_{1}$-receptor, resulting in vasoconstriction, as well as binding to the $\mathrm{AT}_{2}$-receptor, evoking vasodilation [14]. Both receptor subtypes have been identified in the coronary microcirculation $[4,107]$, suggesting that endogenous ANG-II may contribute to the regulation of coronary vascular tone and to the regulation of myocardial perfusion. Under pathological circumstances, i.e. after MI, the renin-angiotensin system is activated, resulting in increased plasma levels of ANG-II, particularly during exercise [34, 43]. Moreover, there is evidence that $\mathrm{AT}_{1}$-receptor density in the viable region of the myocardium is increased early after MI $[62,98]$, suggesting that its vasoconstrictor influence on the coronary vasculature could be increased, which may limit myocardial perfusion thereby exacerbating LV dysfunction.

Contrary to our hypothesis, we observed a loss of ANGII induced vasoconstrictor influence, reflected by the lack of increase in coronary venous $\mathrm{O}_{2}$ tension (Fig. 6), despite increased plasma ANG-II levels and maintained $\mathrm{AT}_{1}$ receptor densities in coronary arterioles isolated from remodelled myocardium of MI swine [68]. It is unlikely that a generalized loss of vasodilator capacity in the remote myocardium contributed to the blunted vasodilator response to the $\mathrm{AT}_{1}$ receptor blocker irbesartan, as we have previously shown that vasodilation produced by nitroprusside is unperturbed [44]. Although an increased $\mathrm{AT}_{2^{-}}$ receptor expression could have acted to limit ANG-II induced vasoconstriction [84] this is unlikely as $\mathrm{AT}_{2}$ mRNA was not altered in coronary arteries from patients with ischemic heart disease [103]. Moreover, the dramatic increases in ANG-II levels that we observed after irbesartan did not result in enhanced, but rather blunted, coronary vasodilation [68]. Therefore, the observation of a reduced
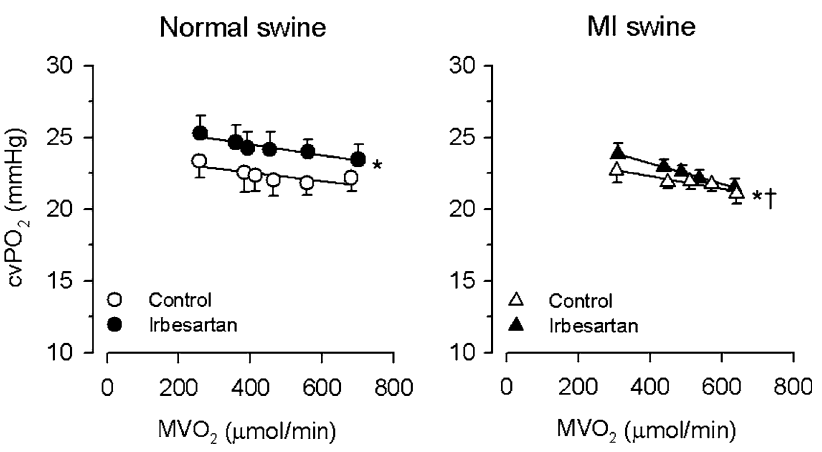

Fig. 6 Effect of $\mathrm{AT}_{1}$-receptor blockade with irbesartan $(1 \mathrm{mg} / \mathrm{kg}$ iv $)$ on the relation between myocardial $\mathrm{O}_{2}$ consumption $\left(\mathrm{MVO}_{2}\right)$ and coronary venous $\mathrm{O}_{2}$ tension $\left(\mathrm{CVPO}_{2}\right)$ in normal swine and swine with a 2-3-week-old myocardial infarction. Data are means $\pm \mathrm{SE}$; $* P<0.05$ versus corresponding control relation, ${ }^{\dagger} P<0.05$ effect of irbesartan different in MI versus Normal animals. Data are from Merkus et al. [68]

vasoconstrictor influence of endogenous ANG-II is best explained by $\mathrm{AT}_{1}$-receptor-desensitization, which is in accordance with studies in dogs with pacing-induced heart failure [78], in rats with pressure-overload LV hypertrophy [63], and in rats with LV remodeling after MI [84], that demonstrated blunted vasoconstrictor responses to exogenous ANG-II.

\subsection{Local metabolic control}

\subsubsection{Adenosine}

Adenosine has been proposed to be a metabolic messenger that regulates coronary resistance vessel tone in response to changes in metabolic needs of the myocardium [5]. However, adenosine receptor blockade with $8 \mathrm{PT}$ and/or augmenting adenosine catabolism with intracoronary adenosine deaminase had either no effect [3] or produced a small decrease $[28,67,93]$ in basal coronary venous $\mathrm{O}_{2}$ tension (reflecting vasoconstriction), but did not interfere with the normal exercise-induced increase in $\mathrm{CBF}$ and $\mathrm{O}_{2}$ delivery [3, 28, 67, 93], indicating that adenosine is not critical for the exercise-induced coronary vasodilation or that loss of adenosine-mediated vasodilation can be compensated for by increased contribution of other vasodilator pathways to maintain adequate metabolic vasodilation.

In contrast to the lack of evidence for an essential role of adenosine in regulation of CBF under physiological conditions, endogenously released adenosine does contribute to coronary vasodilation when there is insufficient supply of $\mathrm{O}_{2}$ [61]. Similarly, adenosine production could be increased in the remodelled myocardium after MI as a result of the perturbations in the myocardial $\mathrm{O}_{2}$ balance $[43,70,108]$. 
However, we found no evidence for an increased contribution of adenosine to regulation of coronary resistance vessel tone in remodelled myocardium of swine with a recent MI [71], as adenosine receptor blockade with 8PT caused a similar decrease in coronary venous $\mathrm{O}_{2}$ tension in post-infarct remodelled hearts and normal hearts both at rest and during exercise (Fig. 7). These findings are in agreement with observations in dogs with pressure-overload LV hypertrophy, in which adenosine receptor blockade did not affect CBF either at rest or during exercise [65].

Several reasons could be forwarded for the failure to observe a larger contribution of adenosine to regulation of coronary resistance vessel tone. First, it is possible that the perturbations in the myocardial $\mathrm{O}_{2}$ balance were too mild to increase adenosine production. Second, the activity of enzymes that regulate tissue adenosine levels may have been altered [16, 17]. For example, the activity of
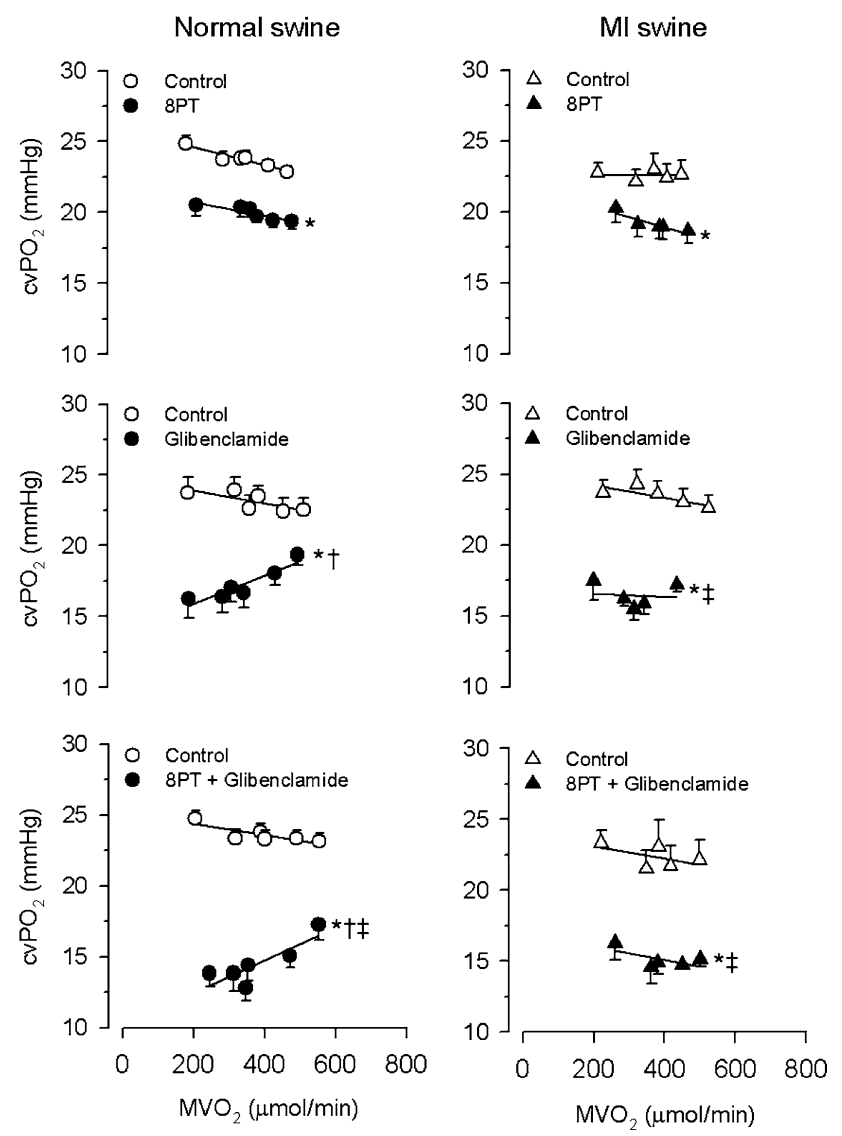

Fig. 7 Effect of the adenosine receptor antagonist 8-phenyltheophylline $\left(8 P T, 5 \mathrm{mg} / \mathrm{kg}\right.$ iv), the $\mathrm{K}_{\mathrm{ATP}}$ channel blocker glibenclamide (Glib, $3 \mathrm{mg} / \mathrm{kg}$ iv) or their combination on myocardial $\mathrm{O}_{2}$ balance in the LV anterior free wall of normal swine and swine with a recent MI. $\mathrm{MVO}_{2}=$ myocardial $\mathrm{O}_{2}$ consumption; $\mathrm{CVPO}_{2}=$ coronary venous $\mathrm{O}_{2}$ tension; Data are mean $\pm \mathrm{SEM}$; Data are mean $\pm \mathrm{SEM}$; $* P \leq 0.05$ versus corresponding control; ${ }^{\dagger} P \leq 0.05$ effect of Glib was blunted at higher $\mathrm{MVO}_{2}$ levels $\left(\mathrm{Glib} \times \mathrm{MVO}_{2}\right) ;{ }^{\ddagger} P \leq 0.05$ effect of Glib different after MI $\left(\mathrm{Glib} \times \mathrm{MVO}_{2} \times \mathrm{MI}\right)$. Data are from Merkus et al. [71] adenosine deaminase, the enzyme responsible for breakdown of adenosine to inosine, was found to be elevated in LV hypertrophy $[10,13,15]$. Furthermore, there is evidence that the activity of cytosolic $5^{\prime}$ nucleotidase, which converts $5^{\prime} \mathrm{AMP}$ to adenosine, is lower in certain models of pressure-overload [13] and volume-overload [10] induced LV hypertrophy, which could be related to intermittent hypoperfusion of the hypertrophic myocardium [41]. Together these enzymatic alterations, which act to decrease myocardial levels of adenosine may have prevented a significant increase in myocardial adenosine levels in the post MI remodelled hearts.

Finally, it is possible that an increased role of adenosine in hypertrophied myocardium is masked by an increased contribution of other vasodilator systems during adenosine receptor blockade, as the process of metabolic vasodilation is thought to be mediated through multiple parallel or redundant pathways. Thus, $\mathrm{K}_{\mathrm{ATP}}$ channel activity may have increased in response to adenosine receptor blockade to compensate for the loss of adenosine-mediated vasodilation. Hence, we evaluated the interactions between these vasodilator pathways.

\subsection{2 $K_{A T P}$ channels}

In addition to the role of $\mathrm{K}_{\mathrm{ATP}}$ channels in the regulation of CBF under physiological conditions [24, 25, 31], there is evidence for an increased $\mathrm{K}_{\mathrm{ATP}}$ channel activity in the coronary circulation of remodelled hearts. For example, in anesthetized dogs with pacing-induced severe heart failure [106], the $K_{\text {ATP }}$ channel blocker glibenclamide resulted in an exaggerated vasoconstrictor response as compared to normal dogs. Interestingly, in dogs subjected to only 1 week of pacing (when LV function was still normal), $\mathrm{K}_{\mathrm{ATP}}$ channel activity was not different from normal dogs [106], suggesting that $K_{\text {ATP }}$ channel activity in the basal resting state was only enhanced in the presence of overt heart failure. Similarly, in awake dogs with compensated pressure-overload induced LV hypertrophy, the reduction in CBF produced by glibenclamide was similar to that in normal dogs [65]. During exercise, however, glibenclamide produced a greater reduction in $\mathrm{CBF}$ in hypertrophied hearts, indicating increased $\mathrm{K}_{\mathrm{ATP}}$-channel contribution to coronary vasodilation when $\mathrm{O}_{2}$ requirements of the hypertrophied heart were augmented [65].

In swine with MI-induced moderate LV remodeling and dysfunction, glibenclamide caused a marked decrease in coronary venous $\mathrm{O}_{2}$ tension in remodelled left ventricle under resting conditions, that was similar to the decrease in coronary venous $\mathrm{O}_{2}$ tension in normal hearts (Fig. 7; [71]). Although the vasoconstriction under resting conditions in response to $\mathrm{K}_{\mathrm{ATP}}$ channel blockade was similar in normal 
and post-MI remodelled hearts, the responses to exercise were different. Thus in normal swine, the effects of $\mathrm{K}_{\mathrm{ATP}}$ channel blockade waned during exercise, suggesting that other vasodilator systems compensated for the loss of $\mathrm{K}_{\mathrm{ATP}}$ channels during exercise. In contrast, in the post-MI remodelled hearts the effects of $\mathrm{K}_{\mathrm{ATP}}$ channel blockade were maintained during exercise. Our findings, which are consistent with the observations in dogs [65], support the hypothesis that $\mathrm{K}_{\mathrm{ATP}}$ channel opening is of greater importance in resistance vessel dilation during exercise in hypertrophied than in normal hearts. It is likely that with the progression from LV dysfunction to overt heart failure, increased $\mathrm{K}_{\mathrm{ATP}}$ channel activity may also become important under resting conditions [106].

\subsubsection{Interaction between $K_{A T P}$ channels and adenosine}

In contrast to the canine heart in which adenosine can act as a back-up system [29, 81], adenosine and $\mathrm{K}_{\mathrm{ATP}}$ channels appear to exert additive vasodilator influences on coronary vasomotor tone in the normal porcine heart [67]. Thus, the coronary vasoconstriction that occurs in response to combined adenosine receptor blockade and $\mathrm{K}_{\mathrm{ATP}}$ channel blockade equalled the sum of the vasoconstriction induced by blockade of the individual pathways. Adenosine mediates its vasodilator effect on porcine coronary resistance vessels via $K_{A T P}, K_{C a}$ and $K_{v}$ channels [9, 46-48] It is therefore possible that following $\mathrm{K}_{\mathrm{ATP}}$ channel blockade adenosine maintained its vasodilator influence via $\mathrm{K}_{\mathrm{Ca}}$ and/ or $\mathrm{K}_{\mathrm{v}}$ channels.

In contrast to the normal porcine heart, the magnitude of the constriction induced in remodelled hearts by combined blockade of adenosine receptors and $\mathrm{K}_{\mathrm{ATP}}$ channels was virtually identical to that produced by blockade of $\mathrm{K}_{\mathrm{ATP}}$ channels alone [71]. These findings could be interpreted to suggest that in remodelled myocardium the vasodilator influence of endogenous adenosine was entirely mediated through opening of $\mathrm{K}_{\mathrm{ATP}}$ channels, observations that are corroborated by findings in pressure-overload hypertrophied canine hearts [65]. Taken together these observations in the porcine and canine coronary circulations suggest that, although the magnitude of the vasodilator influence exerted by endogenous adenosine was similar in normal and remodelled hearts, its effector pathway was different.

\subsection{Endothelial control}

Several studies have indicated that endothelial dysfunction, in particular a decreased production of $\mathrm{NO}$ and an increased production of endothelin, could aggravate LV dysfunction due to the peripheral vasoconstriction-induced increase in LV afterload, coronary vasoconstriction, and increased myocardial $\mathrm{O}_{2}$ consumption [26, 59, 80, 105].

\subsubsection{Nitric oxide}

Clinical studies indicate that chronic heart failure is accompanied by blunted vasodilator responses to endothelium-dependent receptor mediated vasodilators (particularly acetylcholine) in the microcirculation of the LV myocardium [92], leg [45, 57], and forearm [19, 52, 57, 64]. In the canine model of pacing-induced end-stage congestive heart failure, attenuated vasodilator responses of resistance vessels to acetylcholine in vivo have also been observed in the microvasculature of the hindleg circulation $[22,64]$ and the coronary circulation [105]. In swine with a 2-3-week-old MI, we observed reduced vasodilator responses in the systemic and coronary microvasculature to ATP, in doses which we have previously shown to be completely abolished by pretreatment with the eNOSinhibitor NLA [26]. The findings of a blunted ATP-induced vasodilation are in agreement with the hypothesis that agonist-induced eNOS-mediated NO production is blunted 2-3 weeks after MI.

A loss of NO-mediated vasodilation could enhance the progression of LV dysfunction to heart failure. This is supported by studies in dogs with pacing-induced dilated cardiomyopathy, in which the loss of basal NO production in the LV myocardium coincides with the progression from LV dysfunction to overt heart failure [80, 105]. However, in swine with a 2-3-week-old MI, we did not find any evidence of a reduced coronary vasodilator influence of endogenous $\mathrm{NO}$ as decreases in coronary venous $\mathrm{O}_{2}$ tension produced by NLA in resting and exercising MI swine were similar to those of normal swine (Fig. 8). In heart failure patients, studies on the contribution of NO to basal
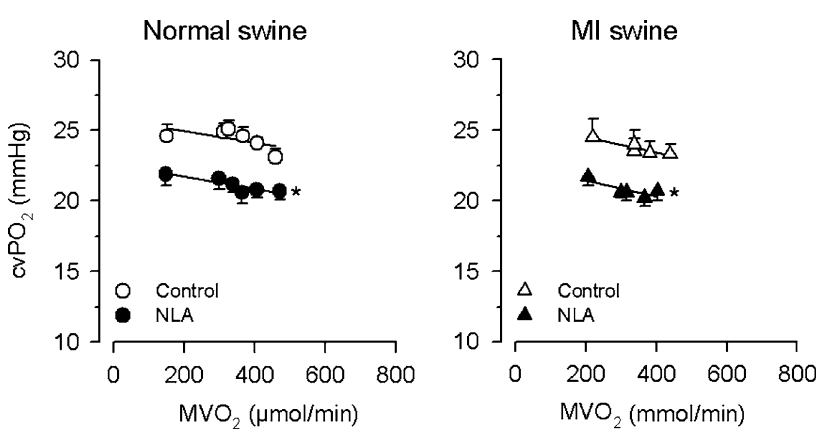

Fig. 8 Effect of inhibition of NO synthase by NLA (20 mg/kg iv) on myocardial $\mathrm{O}_{2}$ extraction and coronary venous $\mathrm{PO}_{2}$ at rest (lying) and during treadmill exercise in MI and N. Data are mean \pm SEM. $* P<0.05$ NLA versus corresponding Control; there were no significant differences in the responses to NLA between MI and N either at rest or during exercise. Data are from Haitsma et al. [44] 
microvascular tone in the forearm, leg, or total systemic bed have yielded equivocal results with responses varying from blunted [45, 58, 64], to maintained [60], and even enhanced [20,42] increases in vascular tone following NO synthase inhibition. It is possible that a maintained or increased NO production as observed in some studies, was the result of increased iNOS expression [21, 79], as part of a generalized inflammatory response in end-stage heart failure, that occurred in the presence of either a decreased $[21,86]$ or increased $[37,50]$ eNOS expression. Since NLA can block all three isoforms of NOS [7], we performed additional experiments, in which we blocked iNOS with aminoguanidine, to determine whether an upregulation of iNOS-mediated NO production masked a reduction in eNOS activity. iNOS blockade had no effect on coronary vasomotor tone, demonstrating that $\mathrm{NO}$ production via iNOS does not contribute significantly to vascular tone in MI swine, and, consequently, that basal and exerciseinduced endothelial NO production is maintained early after MI [44].

The reason for the maintained basal and exerciseinduced NO production in the presence of a blunted vasodilator response to ATP is unclear. However, Traverse et al. [91] have shown that the amount of NO, produced after stimulation with an agonist is larger than the amount of NO produced during moderate exercise $(60 \%$ increase in heart rate). Hence, the maximal capacity of NO production may be reduced, whereas the capacity of eNOS is sufficient to maintain basal and exercise-induced NO production. This explanation is unlikely since agonist-induced dilation is already affected at the lowest dose of administered ATP (which probably releases less NO than strenuous exercise). Moreover, higher doses of ATP still produce more dilation. Another explanation for the divergent results between ATP and exercise-induced increases in NO-production may be that ATP activates eNOS through a different mechanism than shear stress. ATP-induced activation of eNOS is mediated through a calcium-calmodulin dependent pathway [74] whereas shear stress activates eNOS through Aktmediated phosphorylation [18], resulting in calcium-independent activation of eNOS. Hence, it is possible that perturbations in the calcium homeostasis of endothelial cells contributed to the selective impairment of ATPinduced vasodilation in swine with MI.

\subsubsection{Endothelin}

Despite the increased plasma levels of endogenous ET in swine with a 2-3 week old MI, its vasoconstrictor influence on the coronary circulation was reduced (Fig. 9 [69, 70]). To determine whether this was the result of blunted receptor responsiveness or reduced local ET-production, we studied
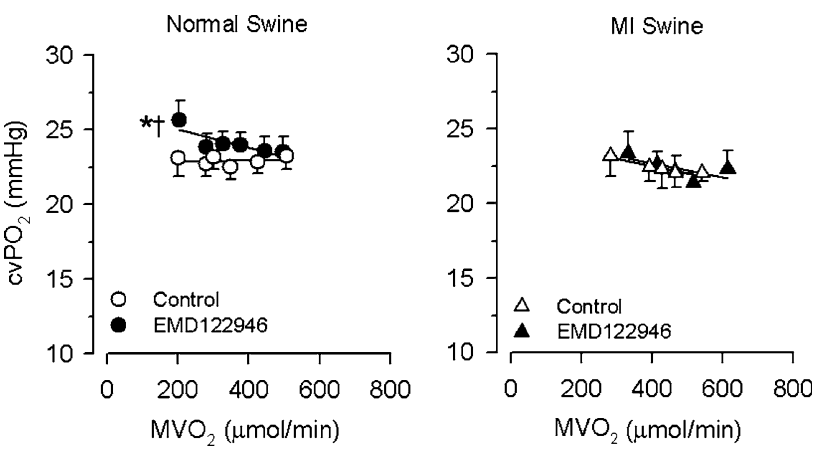

Fig. 9 Effect of $\mathrm{ET}_{\mathrm{A}}$ receptor blockade with EMD (3 mg/kg iv) on myocardial oxygen balance in normal swine and swine with a recent MI. Data are means $\pm \mathrm{SE} ; * P<0.05$ versus corresponding Control relation, ${ }^{\dagger} P<0.05$ effect of EMD waned during exercise. Data are from Merkus et al. [70]

the vasoconstriction induced by exogenous ET. The coronary vasoconstrictor influence to exogenous ET-1 in vivo was reduced after MI, indicating a reduced coronary vascular responsiveness to ET. Paradoxically, a recent study showed that ischemic heart disease results in upregulation of $\mathrm{ET}_{\mathrm{A}}$ and $\mathrm{ET}_{\mathrm{B}}$ receptor mRNA in human coronary arteries [104]. This is in accordance with our measurements in isolated coronary arterioles obtained from sham-operated swine and swine with a MI, which showed that the ET responsiveness in vessels from animals with a MI was actually increased [70]. The discrepancy between the in vivo and the in vitro findings suggests that ET receptor sensitivity is modulated in vivo, and that this modulation is apparently lost in vitro. Possible modulators of ET-receptor sensitivity are adenosine and NO, which have been shown to desensitize ET-receptors on the coronary vasculature [72, 73], and which may have been lost in the in vitro set-up due to lack of surrounding myocardium and intravascular blood flow. However, since we observed similar vasoconstrictor responses to blockade of adenosine receptors and NO production in MI and normal swine, these vasodilators would seem unlikely explanations for the observed reduced ET receptor sensitivity in MI swine in vivo.

In conclusion, our observations suggest that when additional coronary vasodilation is required in the hypertrophied myocardium after MI, withdrawal of the ETmediated vasoconstrictor influence contributes to a shift in vasomotor tone towards vasodilation. These findings may also explain in part why clinical trials of ET-receptor antagonists in heart failure have failed to show therapeutic value of these compounds [40,77].

\subsection{Conclusions and physiological relevance}

Under physiological circumstances, the heart matches its blood supply to the demand of the myocardium by altering 


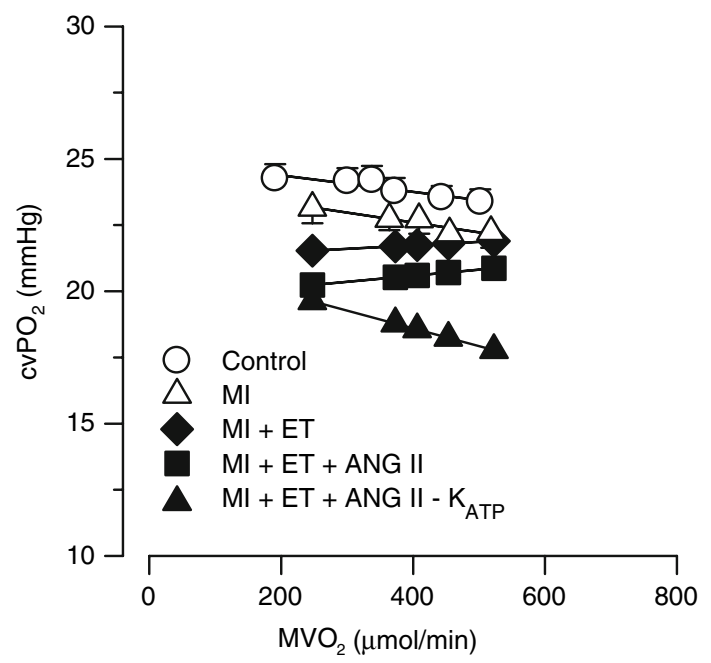

Fig. 10 Myocardial oxygen balance in normal and MI swine. Shown are the actual relations between $\mathrm{MVO}_{2}$ and $\mathrm{CVPO}_{2}$ in 30 normal swine (open circles) and $20 \mathrm{MI}$ swine (open triangles) under control conditions. In addition, we have depicted the computed relations in MI swine if the ET (solid diamonds) and ANG II (solid squares) vasoconstrictor influences (which were both attenuated in MI swine) and the $\mathrm{K}_{\mathrm{ATP}}$ (solid triangles) vasodilator influences (which were enhanced in MI swine) would have been identical to those in normal swine. The graph clearly illustrates that the adaptations in coronary vasomotor control act to blunt perturbations in oxygen balance in remodelled myocardium of swine with a recent MI

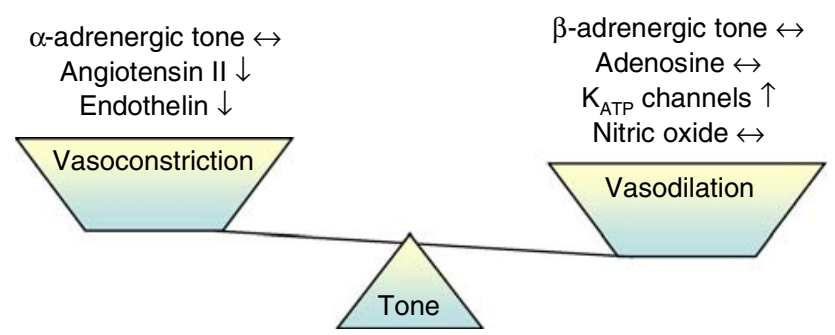

Fig. 11 Alterations in vasomotor balance in the coronary resistance vessels within remodelled myocardium in swine with a $2-3$-week-old myocardial infarction

the balance of vasodilator and vasoconstrictor influences, i.e. an increase in myocardial $\mathrm{O}_{2}$ demand results in an increased influence of vasodilators (opening of $\mathrm{K}_{\mathrm{ATP}}$ channels, NO, adenosine [53], $\beta$-adrenergic vasodilation [27]) and a decreased influence of the potent vasoconstrictor endothelin-1 [66, 69]. Studies from our laboratory performed during the past 10 years have shown that following MI myocardial $\mathrm{O}_{2}$ balance in the remodelled $\mathrm{LV}$ is perturbed, necessitating vasodilation and recruitment of coronary flow reserve, as evidenced by increased opening of $\mathrm{K}_{\mathrm{ATP}}$ channels [71]. Importantly, however, not only an increased $\mathrm{K}_{\mathrm{ATP}}$ channel vasodilator influence, but also blunting of the coronary vasoconstrictor influences of endogenous endothelin [70] and angiotensin II [68], aid in preventing a more significant impairment of oxygen supply to the remodelled myocardium (Figs. 10, 11). Our studies suggest that generalized blunting of vasoconstrictor influences is one of the first adaptive mechanisms to reduce coronary resistance vessel tone and increase myocardial blood supply. This adaptation, which occurs in the healthy porcine heart during acute exercise, also appears operative in remodelled myocardium. Blunting of vasoconstrictor influences may be a physiologically favorable strategy, since it is more energy-efficient to blunt vasoconstrictor influences than to synthesize vasodilators.

Although the shift in coronary tone towards vasodilatation acts to blunt the flow perturbations in the remodelled heart, it does not appear to fully restore myocardial oxygen balance. This is also supported by the observation that $\mathrm{K}_{\mathrm{ATP}}$ channel activation is increased, consistent with the presence of metabolic distress. Whether these perturbations in myocardial oxygen delivery blood are sufficiently severe to contribute to the progressive deterioration of contractile function of the remodelled left ventricle remains to be established, but it is of interest to note that we previously found that troponin I proteolysis occurred in remodelled myocardium, which was associated with a loss of myofilament force development [97]. Intermittent myocardial ischemia, as may occur in remodelled hearts during exercise or excitement, has been shown to be able to promote troponin I proteolysis [38] and could thereby mediate the flow perturbation-induced progressive deterioration of LV function after MI. Definitive proof of our hypothesis must await future studies demonstrating that prevention of such flow perturbations will indeed prevent progressive loss of contractile function of the remodelled porcine left ventricle.

Acknowledgments Dr Merkus is supported by a post-doc stipend from the Netherlands Heart Foundation (2000T042).

Open Access This article is distributed under the terms of the Creative Commons Attribution Noncommercial License which permits any noncommercial use, distribution, and reproduction in any medium, provided the original author(s) and source are credited.

\section{References}

1. Azevedo ER, Parker JD (1999) Parasympathetic control of cardiac sympathetic activity: Normal ventricular function versus congestive heart failure. Circulation 100:274-279

2. Bache RJ (1988) Effects of hypertrophy on the coronary circulation. Prog Cardiovasc Dis 30:403-440

3. Bache RJ, Dai XZ, Schwartz JS et al (1988) Role of adenosine in coronary vasodilation during exercise. Circ Res 62:846-853

4. Batenburg WW, Garrelds IM, Bernasconi CC et al (2004) Angiotensin II type 2 receptor-mediated vasodilation in human coronary microarteries. Circulation 109:2296-2301

5. Berne RM, Rubio R (1974) Regulation of coronary blood flow. Adv Cardiol 12:303-317 
6. Binkley PF, Nunziata E, Haas GJ et al (1991) Parasympathetic withdrawal is an integral component of autonomic imbalance in congestive heart failure: Demonstration in human subjects and verification in a paced canine model of ventricular failure. J Am Coll Cardiol 18:464-472

7. Boer R, Ulrich WR, Klein T et al (2000) The inhibitory potency and selectivity of arginine substrate site nitric-oxide synthase inhibitors is solely determined by their affinity toward the different isoenzymes. Mol Pharmacol 58:1026-1034

8. Bristow MR, Ginsburg R, Umans V et al (1986) Beta ${ }_{1}^{-}$and beta $_{2}$-adrenergic-receptor subpopulations in nonfailing and failing human ventricular myocardium: Coupling of both receptor subtypes to muscle contraction and selective beta ${ }_{1}$ receptor down-regulation in heart failure. Circ Res 59:297-309

9. Cabell F, Weiss DS, Price JM (1994) Inhibition of adenosineinduced coronary vasodilation by block of large-conductance $\mathrm{Ca}^{2+}$-activated $\mathrm{K}^{+}$channels. Am J Physiol 267:H1455-1460

10. Cavallini G, De Tata V, Fierabracci V et al (1992) the enzymatic activity of adenosine metabolism in the rat heart. The effects of cardiac hypertrophy. Cardiologia 37:659-661

11. Chidsey CA, Harrison DC, Braunwald E (1962) Augmentation of plasma norepinephrine response to exercise in patients with congestive heart failure. New Engl J Med 267:650-654

12. Colucci WS, Braunwald E (2001) Pathophysiology of heart failure. In: Braunwald E, Zipes DP (eds) Heart disease, 6th edn. W.B. Saunders company, Libby P. Philadelphia, pp 503-533

13. Czarnowski D, Wojcik B, Langfort J et al (1996) 5'-Nucleotidase and adenosine deaminase activities in hypertrophied rat heart. The effect of tachycardia. Rocz Akad Med Bialymst 41:334-340

14. de Gasparo M, Catt KJ, Inagami T et al (2000) International union of pharmacology. XXIII. The angiotensin II receptors. Pharmacol Rev 52:415-472

15. De Tata V, Gini S, Simonetti I et al (1989) The regional distribution of adenosine-regulating enzymes in the left and right ventricle walls of control and hypertrophic heart. Basic Res Cardiol 84:597-605

16. Deussen A (2000) Metabolic flux rates of adenosine in the heart. Naunyn Schmiedebergs Arch Pharmacol 362:351-363

17. Deussen A (2000) Quantitative integration of different sites of adenosine metabolism in the heart. Ann Biomed Eng 28:877883

18. Dimmeler S, Fleming I, Fisslthaler B et al (1999) Activation of nitric oxide synthase in endothelial cells by Akt-dependent phosphorylation. Nature 399:601-605

19. Drexler H, Hablawetz E, Lu W et al (1992) Effects of inhibition of nitric oxide formation on regional blood flow in experimental myocardial infarction. Circulation 86:255-262

20. Drexler H, Hayoz D, Munzel T et al (1992) Endothelial function in chronic congestive heart failure. Am J Cardiol 69:1596-1601

21. Drexler H, Kastner S, Strobel A et al (1998) Expression, activity and functional significance of inducible nitric oxide synthase in the failing human heart. J Am Coll Cardiol 32:955-963

22. Drexler H, Lu W (1992) Endothelial dysfunction of hindquarter resistance vessels in experimental heart failure. Am J Physiol 262:H1640-H1645

23. Duncker DJ, Haitsma DB, Liem DA et al (2005) Exercise unmasks autonomic dysfunction in swine with a recent myocardial infarction. Cardiovasc Res 65:889-896

24. Duncker DJ, Laxson DD, Lindstrom P et al (1993) Endogenous adenosine and coronary vasoconstriction in hypoperfused myocardium during exercise. Cardiovasc Res 27:1592-1597

25. Duncker DJ, Oei HH, Hu F et al (2001) Role of $\mathrm{K}_{\mathrm{ATP}}^{+}$channels in regulation of systemic, pulmonary, and coronary vasomotor tone in exercising swine. Am J Physiol 280:H22-H33
26. Duncker DJ, Stubenitsky R, Tonino PA et al (2000) Nitric oxide contributes to the regulation of vasomotor tone but does not modulate $\mathrm{O}_{2}$-consumption in exercising swine. Cardiovasc Res 47:738-748

27. Duncker DJ, Stubenitsky R, Verdouw PD (1998) Autonomic control of vasomotion in the porcine coronary circulation during treadmill exercise: evidence for feed-forward beta-adrenergic control. Circ Res 82:1312-1322

28. Duncker DJ, Stubenitsky R, Verdouw PD (1998) Role of adenosine in the regulation of coronary blood flow in swine at rest and during treadmill exercise. Am J Physiol 275:H16631672

29. Duncker DJ, van Zon NS, Pavek TJ et al (1995) Endogenous adenosine mediates coronary vasodilation during exercise after $\mathrm{K}_{\mathrm{ATP}}^{+}$channel blockade. J Clin Invest 95:285-295

30. Eckberg DL, Drabinsky M, Braunwald E (1971) Defective cardiac parasympathetic control in patients with heart disease. $\mathrm{N}$ Engl J Med 285:877-883

31. Farouque HM, Worthley SG, Meredith IT et al (2002) Effect of ATP-sensitive potassium channel inhibition on resting coronary vascular responses in humans. Circ Res 90:231-236

32. Fowler MB, Laser JA, Hopkins GL et al (1986) Assessment of the beta-adrenergic receptor pathway in the intact failing human heart: progressive receptor down-regulation and subsensitivity to agonist response. Circulation 74:1290-1302

33. Francis GS (1991) Heart failure in 1991. Cardiology 78:81-94

34. Francis GS (2001) Pathophysiology of chronic heart failure. Am J Med 110(Suppl 7A):37S-46S

35. Francis GS, Goldsmith SR, Ziesche S et al (1985) Relative attenuation of sympathetic drive during exercise in patients with congestive heart failure. J Am Coll Cardiol 5:832-839

36. Francis GS, Goldsmith SR, Ziesche SM et al (1982) Response of plasma norepinephrine and epinephrine to dynamic exercise in patients with congestive heart failure. Am J Cardiol 49:11521156

37. Fukuchi M, Hussain SN, Giaid A (1998) Heterogeneous expression and activity of endothelial and inducible nitric oxide synthases in end-stage human heart failure: their relation to lesion site and beta-adrenergic receptor therapy. Circulation 98:132-139

38. Gao WD, Atar D, Liu Y et al (1997) Role of troponin I proteolysis in the pathogenesis of stunned myocardium. Circ Res 80:393-399

39. Gorman MW, Tune JD, Richmond KN et al (2000) Feedforward sympathetic coronary vasodilation in exercising dogs. J Appl Physiol 89:1892-1902

40. Gottlieb SS (2003) The neurohormonal paradigm: Have we gone too far? J Am College Cardiol 41:1458-1459

41. Gustafson LA, Kroll K (1998) Downregulation of $5^{\prime}$-nucleotidase in rabbit heart during coronary underperfusion. Am J Physiol 274:H529-538

42. Habib F, Dutka D, Crossman D et al (1994) Enhanced basal nitric oxide production in heart failure: another failed counterregulatory vasodilator mechanism? Lancet 344:371-373

43. Haitsma DB, Bac D, Raja N et al (2001) Minimal impairment of myocardial blood flow responses to exercise in the remodeled left ventricle early after myocardial infarction, despite significant hemodynamic and neurohumoral alterations. Cardiovasc Res 52:471-428

44. Haitsma DB, Merkus D, Vermeulen J et al (2002) Nitric oxide production is maintained in exercising swine with chronic left ventricular dysfunction. Am J Physiol 282:H2198-H2209

45. Hambrecht R, Fiehn E, Weigl C et al (1998) Regular physical exercise corrects endothelial dysfunction and improves exercise capacity in patients with chronic heart failure. Circulation 98:2709-2715 
46. Heaps CL, Bowles DK (2002) Gender-specific $\mathrm{K}^{+}$-channel contribution to adenosine-induced relaxation in coronary arterioles. J Appl Physiol 92:550-558

47. Hein TW, Belardinelli L, Kuo L (1999) Adenosine A $^{2 A}$ receptors mediate coronary microvascular dilation to adenosine: role of nitric oxide and ATP-sensitive potassium channels. J Pharmacol Exp Ther 291:655-664

48. Hein TW, Kuo L (1999) cAMP-independent dilation of coronary arterioles to adenosine: role of nitric oxide, $\mathrm{G}$ proteins, and $\mathrm{K}_{\mathrm{ATP}}$ channels. Circ Res 85:634-642

49. Helmer GA, McKirnan MD, Shabetai R et al (1996) Regional deficits of myocardial blood flow and function in left ventricular pacing-induced heart failure. Circulation 94:2260-2267

50. Heymes C, Vanderheyden M, Bronzwaer JG et al (1999) Endomyocardial nitric oxide synthase and left ventricular preload reserve in dilated cardiomyopathy. Circulation 99:3009-3016

51. Heyndrickx GR, Muylaert P, Pannier JL (1982) Alpha-adrenergic control of oxygen delivery to myocardium during exercise in conscious dogs. Am J Physiol 242:H805-H809

52. Hirooka Y, Imaizumi T, Tagawa $T$ et al (1994) Effects of 1-arginine on impaired acetylcholine-induced and ischemic vasodilation of the forearm in patients with heart failure. Circulation 90:658-668

53. Ishibashi Y, Duncker DJ, Zhang J et al (1998) ATP-sensitive $\mathrm{K}^{+}$ channels, adenosine, and nitric oxide-mediated mechanisms account for coronary vasodilation during exercise. Circ Res 82:346-359

54. Kalkman EA, Bilgin YM, van Haren P et al (1996) Determinants of coronary reserve in rats subjected to coronary artery ligation or aortic banding. Cardiovasc Res 32:1088-1095

55. Karam R, Healy BP, Wicker P (1990) Coronary reserve is depressed in postmyocardial infarction reactive cardiac hypertrophy. Circulation 81:238-246

56. Katz AM (2000) Heart failure, pathophysiology, molecular biology, and clinical management. Lippincott Williams \& Wilkins, Philadelphia

57. Katz SD, Biasucci L, Sabba C et al (1992) Impaired endothelium-mediated vasodilation in the peripheral vasculature of patients with congestive heart failure. J Am Coll Cardiol 19:918-925

58. Katz SD, Krum H, Khan $\mathrm{T}$ et al (1996) Exercise-induced vasodilation in forearm circulation of normal subjects and patients with congestive heart failure: Role of endotheliumderived nitric oxide. J Am Coll Cardiol 28:585-590

59. Kiowski W, Sutsch G, Schalcher C et al (1998) Endothelial control of vascular tone in chronic heart failure. J Cardiovasc Pharmacol 32:S67-S73

60. Kubo SH, Rector TS, Bank AJ et al (1994) Lack of contribution of nitric oxide to basal vasomotor tone in heart failure. Am J Cardiol 74:1133-1136

61. Laxson DD, Homans DC, Bache RJ (1993) Inhibition of adenosine-mediated coronary vasodilation exacerbates myocardial ischemia during exercise. Am J Physiol 265:H1471-1477

62. Lefroy DC, Wharton J, Crake T et al (1996) Regional changes in angiotensin II receptor density after experimental myocardial infarction. J Mol Cell Cardiol 28:429-440

63. Lopez JJ, Lorell BH, Ingelfinger JR et al (1994) Distribution and function of cardiac angiotensin $\mathrm{AT}_{1}$ - and $\mathrm{AT}_{2}$-receptor subtypes in hypertrophied rat hearts. Am J Physiol 267:H844-852

64. Maguire SM, Nugent AG, McGurk C et al (1998) Abnormal vascular responses in human chronic cardiac failure are both endothelium dependent and endothelium independent. Heart 80:141-145

65. Melchert PJ, Duncker DJ, Traverse JH et al (1999) Role of $\mathrm{K}_{\mathrm{ATP}}^{+}$channels and adenosine in regulation of coronary blood flow in the hypertrophied left ventricle. Am J Physiol 277:H617-H625

66. Merkus D, Duncker DJ, Chilian WM (2002) Metabolic regulation of coronary vascular tone: Role of endothelin-1. Am J Physiol 283:H1915-H1921

67. Merkus D, Haitsma DB, Fung TY et al (2003) Coronary blood flow regulation in exercising swine involves parallel rather than redundant vasodilator pathways. Am J Physiol 285:H424-H433

68. Merkus D, Haitsma DB, Sorop O et al (2006) Coronary vasoconstrictor influence of angiotensin II is reduced in remodeled myocardium after myocardial infarction. Am $\mathrm{J}$ Physiol 291:H2082-2089

69. Merkus D, Houweling B, Mirza A et al (2003) Contribution of endothelin and its receptors to the regulation of vascular tone during exercise is different in the systemic, coronary and pulmonary circulation. Cardiovasc Res 59:745-754

70. Merkus D, Houweling B, van den Meiracker AH et al (2005) Contribution of endothelin to coronary vasomotor tone is abolished after myocardial infarction. Am J Physiol 288:H871-H880

71. Merkus D, Houweling B, van Vliet M et al (2005) Contribution of $\mathrm{K}_{\mathrm{ATP}}^{+}$channels to coronary vasomotor tone regulation is enhanced in exercising swine with a recent myocardial infarction. Am J Physiol Heart Circ Physiol 288:H1306-H1313

72. Merkus D, Sorop O, Houweling B et al (2006) NO and prostanoids blunt endothelin-mediated coronary vasoconstrictor influence in exercising swine. Am J Physiol 291:H2075H2081

73. Merkus D, Stepp DW, Jones DW et al (2000) Adenosine preconditions against endothelin-induced constriction of coronary arterioles. Am J Physiol 279:H2593-H2597

74. Motte S, Communi D, Pirotton S et al (1995) Involvement of multiple receptors in the actions of extracellular ATP: the example of vascular endothelial cells. Int J Biochem Cell Biol 27:1-7

75. Narula J, Haider N, Arbustini E et al (2006) Mechanisms of disease: apoptosis in heart failure-seeing hope in death. Nat Clin Pract Cardiovasc Med 3:681-688

76. Nolan J, Flapan AD, Capewell S et al (1992) Decreased cardiac parasympathetic activity in chronic heart failure and its relation to left ventricular function. Br Heart J 67:482-485

77. O'Connor CM, Gattis WA, Adams KF Jr et al (2003) Tezosentan in patients with acute heart failure and acute coronary syndromes: results of the randomized intravenous tezosentan study (RITZ-4). J Am Coll Cardiol 41:1452-1457

78. Oikawa Y, Maehara K, Saito T et al (2001) Attenuation of angiotensin II-mediated coronary vasoconstriction and vasodilatory action of angiotensin-converting enzyme inhibitor in pacing-induced heart failure in dogs. J Am Coll Cardiol 38:1188-1194

79. Orus J, Heras M, Morales-Ruiz M et al (2000) Nitric oxide synthase II mRNA expression in cardiac tissue of patients with heart failure undergoing cardiac transplantation. J Heart Lung Transplant 19:139-144

80. Recchia FA, McConnell PI, Bernstein RD et al (1998) Reduced nitric oxide production and altered myocardial metabolism during the decompensation of pacing-induced heart failure in the conscious dog. Circ Res 83:969-979

81. Samaha FF, Heineman FW, Ince C et al (1992) ATP-sensitive potassium channel is essential to maintain basal coronary vascular tone in vivo. Am J Physiol 262:C1220-C1227

82. Schaper W, Remijsen P, Xhonneux R (1969) The size of myocardial infarction after experimental coronary artery ligation. $\mathrm{Z}$ Kreislaufforsch 58:904-909

83. Schrier RW, Abraham WT (1999) Hormones and hemodynamics in heart failure. N Engl J Med 341:577-585 
84. Schuijt MP, Basdew M, van Veghel R et al (2001) $\mathrm{AT}_{2}$ receptormediated vasodilation in the heart: effect of myocardial infarction. Am J Physiol Heart Circ Physiol 281:H2590-2596

85. Shannon RP, Komamura K, Shen YT et al (1993) Impaired regional subendocardial coronary flow reserve in conscious dogs with pacing-induced heart failure. Am J Physiol 265:H801-H809

86. Smith CJ, Sun D, Hoegler C et al (1996) Reduced gene expression of vascular endothelial no synthase and cyclooxygenase-1 in heart failure. Circ Res 78:58-64

87. Spinale FG (2007) Myocardial matrix remodeling and the matrix metalloproteinases: influence on cardiac form and function. Physiol Rev 87:1285-1342

88. Spinale FG, Grine RC, Tempel GE et al (1992) Alterations in the myocardial capillary vasculature accompany tachycardiainduced cardiomyopathy. Basic Res Cardiol 87:65-79

89. Spinale FG, Hendrick DA, Crawford FA et al (1990) Chronic supraventricular tachycardia causes ventricular dysfunction and subendocardial injury in swine. Am J Physiol 259:H218-H229

90. Traverse JH, Melchert P, Pierpont GL et al (1999) Regulation of myocardial blood flow by oxygen consumption is maintained in the failing heart during exercise. Circ Res 84:401-408

91. Traverse JH, Wang YL, Du R et al (2000) Coronary nitric oxide production in response to exercise and endothelium-dependent agonists. Circulation 101:2526-2531

92. Treasure CB, Vita JA, Cox DA et al (1990) Endotheliumdependent dilation of the coronary microvasculature is impaired in dilated cardiomyopathy. Circulation 81:772-779

93. Tune JD, Richmond KN, Gorman MW et al (2000) Adenosine is not responsible for local metabolic control of coronary blood flow in dogs during exercise. Am J Physiol 278:H74-H84

94. van den Heuvel AF, Bax JJ, Blanksma PK et al (2002) Abnormalities in myocardial contractility, metabolism and perfusion reserve in non-stenotic coronary segments in heart failure patients. Cardiovasc Res 55:97-103

95. van den Heuvel AF, Blanksma PK, Siebelink HM et al (2001) Impairment of myocardial blood flow reserve in patients with asymptomatic left ventricular dysfunction: effects of ACE-inhibition with perindopril. Int $\mathbf{J}$ Cardiovasc Imaging 17:353-359

96. Van der Giessen WJ, Van Woerkens LJ, Duncker DJ et al (1989) Acute hemodynamic effects of nisoldipine and pimobendan in conscious pigs with chronic heart failure. J Cardiovasc Pharmacol 14:653-658

97. van der Velden J, Merkus D, Klarenbeek BR et al (2004) Alterations in myofilament function contribute to left ventricular dysfunction in pigs early after myocardial infarction. Circ Res 95:e85-e95

98. Van Kats JP, Duncker DJ, Haitsma DB et al (2000) Angiotensinconverting enzyme inhibition and angiotensin II type 1 receptor blockade prevent cardiac remodeling in pigs after myocardial infarction: role of tissue angiotensin II. Circulation 102:15561563

99. van Veldhuisen DJ, van den Heuvel AF, Blanksma PK et al (1998) Ischemia and left ventricular dysfunction: a reciprocal relation? J Cardiovasc Pharmacol 32(Suppl 1):S46-51

100. van Woerkens LJ, van der Giessen WJ, Verdouw PD (1993) Cardiovascular effects of dopamine and dobutamine in conscious pigs with chronic heart failure. Crit Care Med 21:420-424

101. Vatner DE, Asai K, Iwase M et al (1999) Beta-adrenergic receptor-G protein-adenylyl cyclase signal transduction in the failing heart. Am J Cardiol 83:80H-85H

102. Vatner SF, Hittinger L (1993) Myocardial perfusion dependent and independent mechanisms of regional myocardial dysfunction in hypertrophy. Basic Res Cardiol 88:81-95

103. Wackenfors A, Emilson M, Ingemansson R et al (2004) Ischemic heart disease down-regulates angiotensin type 1 receptor mRNA in human coronary arteries. Eur $\mathrm{J}$ Pharmacol 503:147-153

104. Wackenfors A, Emilson M, Ingemansson R et al (2004) Ischemic heart disease induce upregulation of endothelin receptor mrna in human coronary arteries. Eur J Pharmacol 484:103-109

105. Wang J, Seyedi N, Xu XB et al (1994) Defective endotheliummediated control of coronary circulation in conscious dogs after heart failure. Am J Physiol 266:H670-680

106. Yamamoto M, Egashira K, Arimura K et al (2000) Coronary vascular $\mathrm{K}_{\text {ATP }}^{+}$channels contribute to the maintenance of myocardial perfusion in dogs with pacing-induced heart failure. Jpn Circ J 64:701-707

107. Zhang C, Hein TW, Wang W et al (2003) Divergent roles of angiotensin $\mathrm{II}_{\mathrm{AT}_{1}}$ and $\mathrm{AT}_{2}$ receptors in modulating coronary microvascular function. Circ Res 92:322-329

108. Zhang J, Wilke N, Wang Y et al (1996) Functional and bioenergetic consequences of postinfarction left ventricular remodeling in a new porcine model. MRI and ${ }^{31} \mathrm{P}-\mathrm{MRS}$ study. Circulation 94:1089-1100

109. Zhao G, Shen W, Xu X et al (1995) Selective impairment of vagally mediated, nitric oxide-dependent coronary vasodilation in conscious dogs after pacing-induced heart failure. Circulation 91:2655-2663 